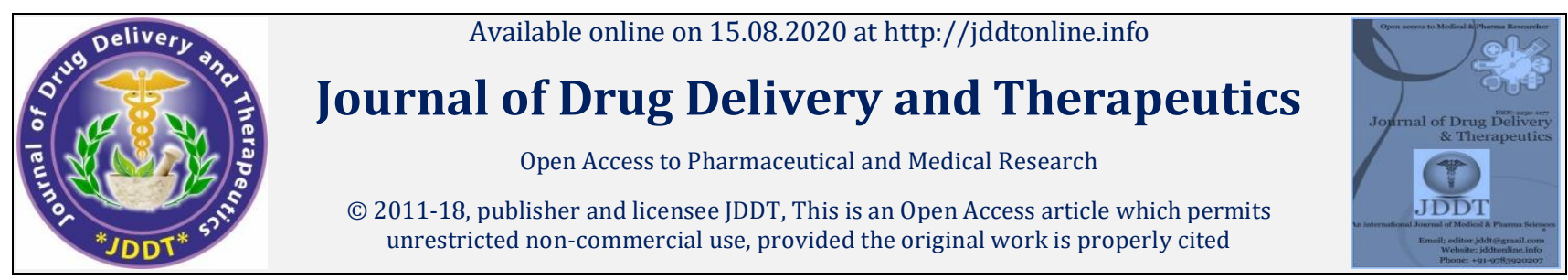

Open Access

Research Article

\title{
Comparative extraction, phytochemical screening and in vitro biological activities of Eclipta prostrata extract
}

\author{
Zafar Alam Khan1, Salaj Khare'2, B.K. Dubey ${ }^{1}$ \\ ${ }^{1}$ TIT- Pharmacy Education and Research, Bhopal, India \\ ${ }^{2}$ Pharmacology Departments, TIT-Pharmacy Education and Research, Bhopal, India
}

\begin{abstract}
Medicinal plants possess therapeutic potential and are used to treat various diseases around the world. Eclipta prostrate (L.) is a medicinal herb that has extensive application in the native medicinal system. In any therapeutic activity chemical constituents play an important role. Eclipta prostrata has been investigated in this study for its antioxidant, antimicrobial and antidiabetic activity in vitro. The well-known research protocol available in the literature established qualitative analysis of the different phytochemical constituents and quantitative analysis of total phenol and flavonoids. The hydroalcoholic extracts of the leaves and seeds of Eclipta prostrata exhibited significant and dose-dependent antioxidant activity including ability to donate electron. To analyze the antimicrobial activity, Leaves hydroalcoholic extracts and Eclipta prostrate seeds were tested against two selected strains using a well-diffusion method and showing significant inhibitory action against all the strain tested. In addition, the dose-dependent $\alpha$-amylase inhibitory activity with an IC50 value of acarbose, leaves, and seed extract was found to be $364.89 \mu \mathrm{g} / \mathrm{ml}$ and $438.43 \mu \mathrm{g} / \mathrm{ml}$, respectively, indicating that Eclipta prostrate is a promising source as an herbal medicine.
\end{abstract}

Keywords: Eclipta prostrate, Phytochemical Analysis, Antioxidant, Antimicrobial, Antidiabetic Activity.

Article Info: Received 11 June 2020; Review Completed 18 July 2020; Accepted 29 July 2020; Available online 15 August 2020

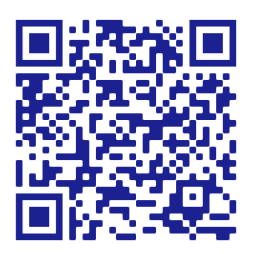

Cite this article as:

Khan ZA, Khare S, Dubey BK, Comparative extraction, phytochemical screening and in vitro biological activities of Eclipta prostrata extract, Journal of Drug Delivery and Therapeutics. 2020; 10(4-s):148-152

http://dx.doi.org/10.22270/jddt.v10i4-s.4263

Zafar Alam Khan, TIT- Pharmacy Education and Research, Bhopal, India

\section{INTRODUCTION}

Natural medicines, often from plants, have acquired worldwide popularity in healthcare promotion and have been used as alternative or complementary pharmaceutical medicine due to the toxicity and side effects of prescription drugs 1. Furthermore, natural products are not only regarded as a abundant source of structurally complex substances with a wide variety of biological activities but also as a key source of synthesized drugs 1,2 . Examining the pharmaceutical properties of medicinal plants and analyzing their natural products is therefore an important aspect when developing alternative or adjunctive therapies. In medicinal plants, the biological and pharmaceutical activities are mostly mediated by the presence of secondary metabolites, including phenolic and flavonoid compounds. These compounds exhibit a wide variety of pharmaceutical properties, including antioxidant, antimicrobial, antiinflammatory, and anticancer properties ${ }^{3}$. Although good sources of these compounds are known to be a variety of plants, their content depends on a number of factors including climatic conditions, material ripeness, tissues, and genetic factors ${ }^{4}$. Eclipta prostrate (L.) also known as Eclipta alba (L.) is a herbaceous annual species, commonly referred to as false daisy. The leaves are opposite, sessile and lanceolate belonging to the family Asteraceae. It is an erect or prostrate, much branched, roughly hairy, annual, rooting at the nodes; It is also known as Bhringaraj and Karisilakanni, a growing weed that grows to $6000 \mathrm{ft}$ in all of India. The genus name comes from the Greek word meaning "Deficient," with reference to the absence of the bristles and awns on the fruits. The specific Eclipta prostrate means white which refers to the color of the flowers. Main active principles consist of coumestans like wedelolactone, desmethylwedelolactone 5 furanocoumarins, eclalbatin 6 oleanane \& taraxastane glycosides 7-8 Eclipta prostrate (L.) was used in various parts of tropical and subtropical regions such as South America, Asia and Africa. It is an active ingredient of many herbal formulations prescribed for liver disease and has an effect on the generation of liver cells. It is used in hepatic and spleen enlargement as a tonic and diuretic. It is used also for catarrhal jaundice and skin diseases 9. The present investigation was therefore conducted to determine the phytochemical constituents, antimicrobial activity, and antidiabetic and antioxidant activity of the Eclipta prostrate extracts with the intention of motivating the use of plant components with less adverse effects. 


\section{MATERIALS AND METHODS}

\section{Plant material}

Eclipta prostrate leaves and seeds were obtained from the local region of Bhopal (M.P.), separating the leaves and seeds and washing them with sterile purified water to avoid adhering dust particles and other undesirable materials. The leaf and seed was air dried under room temperature. The dried plant leaves samples were cut and grinded to make it in powder form.The powdered samples were stored in clean, dry and sterile container for further use.

\section{Chemical reagents}

All the chemicals used in this study were obtained from $\mathrm{Hi}$ Media Laboratories Pvt. Ltd. Mumbai, India), SD Fine- Chem. Ltd. (Mumbai, India) and SRL Pvt. Ltd. (Mumbai, India). All the chemicals used in this study were of analytical grade. Quercetin and gallic acid was kindly provided by Scan Research Laboratories, Bhopal (India).

\section{Extraction procedure}

The shade dried material was coarsely powdered and subjected to extraction with petroleum ether by maceration. The extraction was continued till the defatting of the material had taken place. 36 gram of leaves and 24 gram of seeds dried powdered of Eclipta prostrate has been extracted with hydroalcoholic solvent (methanol: water, 70:30) using maceration process for $48 \mathrm{hrs}$, filtered and dried using vacuum evaporator at $40^{\circ} \mathrm{C} 10$.

\section{Qualitative phytochemical analysis of plant extract}

The extracts of leaves and seeds collected from the Eclipta prostrate were subjected to preliminary phytochemical analysis by Khandelwal and Kokate using reported methods 11,12. The extract was screened to determine the presence or absence of different active constituents, such as phenolic compounds, carbohydrates, flavonoids, glycosides, saponins, alkaloids, fats or fixed oils, protein and amino acid and tannins.

\section{Quantification of Secondary Metabolites}

Quantitative analysis is an important tool for the determination of quantity of phytoconstituents present in plant extracts. For this TPC and TFC are determined. Hydroalcoholic extract obtained from Eclipta prostrate plant material (leaves and seeds) subjected to estimate the presence of TPC and TFC by standard procedure.

\section{Total Phenol Determination}

The total phenolic content was determined using the modified method of Olufunmiso et al ${ }^{12}$. A volume of $2 \mathrm{ml}$ of Eclipta prostrate hydroalcoholic extracts or standard was mixed with $1 \mathrm{ml}$ of Folin Ciocalteau reagent (previously diluted with distilled water $1: 10 \mathrm{v} / \mathrm{v})$ and $1 \mathrm{ml}(7.5 \mathrm{~g} / \mathrm{l})$ of sodium carbonate separate for leaves and seeds. The mixture was vortexed for $15 \mathrm{~s}$ and allowed to stand for $15 \mathrm{~min}$ at $40^{\circ} \mathrm{C}$ for colour development. The absorbance was measured at $765 \mathrm{~nm}$ using UV/visible spectrophotometer. The total phenolic content was calculated from the standard graph of gallic acid and the results were expressed as gallic acid equivalent (mg/100mg).

\section{Total Flavonoids Determination}

The total flavonoid content was determined using the method of Olufunmiso et al 13 . $1 \mathrm{ml}$ of $2 \% \mathrm{AlCl}_{3}$ methanolic solution was added to $1 \mathrm{ml}$ of extracts (leaves and seeds separately) or standard and allowed to stand for $60 \mathrm{~min}$ at room temperature; the absorbance of the reaction mixture was measured at $420 \mathrm{~nm}$ using UV/visible spectrophotometer The content of flavonoids was calculated using standard graph of quercetin and the results were expressed as quercetin equivalent (mg/100mg).

\section{Antioxidant activity}

\section{DPPH radical scavenging assay}

DPPH scavenging activity was measured by modified method of Olufunmiso et al ${ }^{13}$. DPPH scavenging activity was measured by the spectrophotometer. Stock solution $6 \mathrm{mg}$ in $100 \mathrm{ml}$ methanol) was prepared such that $1.5 \mathrm{ml}$ of it in 1.5 $\mathrm{ml}$ of methanol gave an initial absorbance. Decrease in the absorbance in presence of sample extract at different concentration $(10-100 \mu \mathrm{g} / \mathrm{ml})$ was noted after 15 minutes. $1.5 \mathrm{ml}$ of DPPH solution was taken and volume made till $3 \mathrm{ml}$ with methanol, absorbance was taken immediately at 517 $\mathrm{nm}$ for control reading. $1.5 \mathrm{ml}$ of DPPH and $1.5 \mathrm{ml}$ of the test sample of different concentration were put in a series of volumetric flasks and final volume was adjusted to $3 \mathrm{ml}$ with methanol. Three test samples were taken and each processed similarly. Finally the mean was taken. Absorbance at zero time was taken for each concentration. Final decrease in absorbance was noted of DPPH with the sample at different concentration after 15 minutes at $517 \mathrm{~nm}$. The percentage inhibition of free radical DPPH was calculated from the following equation: $\%$ inhibition $=[$ (absorbance of control - absorbance of sample)/absorbance of control] $\times$ $100 \%$. Though the activity is expressed as $50 \%$ inhibitory concentration (IC50), IC50 was calculated based on the percentage of DPPH radicals scavenged. The lower the IC50 value, the higher is the antioxidant activity.

\section{Antimicrobial activity}

The well diffusion method was used to determine the antibacterial activity of the extract prepared from the Eclipta prostrate using standard procedure of Bauer et al 14. The drug used in standard preparation was ciprofloxacin of IP grade. The antibacterial activity was performed by using $24 \mathrm{hr}$ culture of Staphylococcus aureus and Klebsiella pneumoniae. There were 3 concentration used which are 25 , 50 and $100 \mathrm{mg} / \mathrm{ml}$ for each extracted phytochemicals in antibiogram studies. It's essential feature is the placing of wells with the antibiotics on the surfaces of agar immediately after inoculation with the organism tested. Undiluted overnight broth cultures should never be used as inoculums. The plates were incubated at $37^{\circ} \mathrm{C}$ for $24 \mathrm{hr}$. and then examined for clear zones of inhibition around the wells impregnated with particular concentration of drug. The diameter of zone of inhibition of each wall was recorded.

\section{Anti-diabetic activity}

\section{Inhibition of alpha amylase enzyme}

Preparation of standard: $10 \mathrm{mg}$ acarbose was dissolved in $10 \mathrm{ml}$ methanol, and various aliquots of $100-1000 \mu \mathrm{g} / \mathrm{ml}$ were prepared in methanol.

Preparation of sample: $10 \mathrm{mg}$ of dried extract was extracted with $10 \mathrm{ml}$ methanol. $500 \mu \mathrm{l}$ of this extract solution was used for the estimation of enzyme inhibition.

Method: A total of $500 \mu \mathrm{l}$ of test samples and standard drug $(100-500 \mu \mathrm{g} / \mathrm{ml})$ were added to $500 \mu \mathrm{l}$ of $0.20 \mathrm{mM}$ phosphate buffer ( $\mathrm{pH} 6.9)$ containing $\alpha$-amylase $(0.5 \mathrm{mg} / \mathrm{ml})$ solution and were incubated at $25^{\circ} \mathrm{C}$ for $10 \mathrm{~min}$. After these $500 \mu \mathrm{l}$ of a $1 \%$ starch solution in $0.02 \mathrm{M}$ sodium phosphate buffer ( $\mathrm{pH}$ 6.9) was added to each tube. The reaction mixtures were then incubated at $25^{\circ} \mathrm{C}$ for $10 \mathrm{~min}$. The reaction was stopped with $1.0 \mathrm{ml}$ of 3,5 dinitrosalicylic acid colour reagent. The test tubes were then incubated in a 
boiling water bath for $5 \mathrm{~min}$, cooled to room temperature. The reaction mixture was then diluted after adding $10 \mathrm{ml}$ distilled water and absorbance was measured at $540 \mathrm{~nm}$. Control represent $100 \%$ enzyme activity and were conducted in similar way by replacing extract with vehicle.

\section{RESULTS AND DISCUSSION}

The crude extracts so obtained after the maceration extraction process, extracts was further concentrated on water bath for evaporate the solvents completely to obtain the actual yield of extraction. To obtain the percentage yield of extraction is very important phenomenon in phytochemical extraction to evaluate the standard extraction efficiency for a particular plant, different parts of same plant or different solvents used. The yield of extracts obtained from sample using Pet ether and hydroalcoholic as solvents are depicted in the Table 1.

Table 1: \% Yield of plant material

\begin{tabular}{|c|c|c|c|}
\hline \multirow{2}{*}{ S. No. } & Solvent & \multicolumn{2}{|c|}{ \% Yield } \\
\cline { 3 - 4 } & & Leaves extract & Seeds extract \\
\hline 2. & Hydroalcoholic & 2.44 & 1.86 \\
\hline
\end{tabular}

Phytochemical analysis of hydroalcoholic extracts of leaf sample of Eclipta prostrate showed the presence of alkaloids, flavonoid, phenols, amino acid, protein, saponins, carbohydrate and diterpines while, tannins and glycosides were not detected. From hydroalcoholic seed extract exhibited the presence of flavonoid, phenols, amino acid, protein but alkaloids, glycosides and carbohydrate and saponons were reported to be absent (Table 2).

Table 2: Phytochemical screening of extract of Tinospora crispa

\begin{tabular}{|c|c|c|c|}
\hline \multirow[t]{2}{*}{ S. No. } & \multirow[t]{2}{*}{ Constituents } & \multicolumn{2}{|c|}{ Hydroalcoholic extract } \\
\hline & & Leaves extract & Seeds extract \\
\hline 1. & $\begin{array}{c}\text { Alkaloids } \\
\text { Dragendroff's test } \\
\text { Hager's test }\end{array}$ & $\begin{array}{l}\text {-ve } \\
+ \text { ve }\end{array}$ & $\begin{array}{l}\text {-ve } \\
\text {-ve }\end{array}$ \\
\hline 2. & $\begin{array}{l}\text { Glycosides } \\
\text { Legal's test }\end{array}$ & -ve & -ve \\
\hline 3. & $\begin{array}{c}\text { Flavonoids } \\
\text { Lead acetate } \\
\text { Alkaline test }\end{array}$ & $\begin{array}{l}\text { +ve } \\
+ \text { ve }\end{array}$ & $\begin{array}{l}+\mathrm{ve} \\
-\mathrm{ve}\end{array}$ \\
\hline 4. & $\begin{array}{c}\text { Phenol } \\
\text { Ferric chloride test }\end{array}$ & + ve & $+\mathrm{ve}$ \\
\hline 5. & $\begin{array}{c}\text { Proteins } \\
\text { Xanthoproteic test }\end{array}$ & +ve & +ve \\
\hline 6. & $\begin{array}{l}\text { Carbohydrates } \\
\text { Fehling's test }\end{array}$ & $+\mathrm{ve}$ & -ve \\
\hline 7. & $\begin{array}{l}\text { Saponins } \\
\text { Foam test }\end{array}$ & +ve & -ve \\
\hline 8. & $\begin{array}{c}\text { Diterpenes } \\
\text { Copper acetate test }\end{array}$ & $+\mathrm{ve}$ & -ve \\
\hline 9. & $\begin{array}{c}\text { Tannins } \\
\text { Gelatin Test }\end{array}$ & -ve & -ve \\
\hline
\end{tabular}

Total phenol content was expressed as $\mathrm{mg} / 100 \mathrm{mg}$ of gallic acid equivalent of dry extract sample using the equation obtained from the calibration curve: $\mathrm{Y}=0.011 \mathrm{X}+0.011, \mathrm{R}^{2}=$ 0.998 , where $\mathrm{X}$ is the gallic acid equivalent (GAE) and $\mathrm{Y}$ is the absorbance. Total flavonoids content was calculated as quercetin equivalent $(\mathrm{mg} / 100 \mathrm{mg})$ using the equation based on the calibration curve: $\mathrm{Y}=0.032 \mathrm{X}+0.018, \mathrm{R}^{2}=0.998$, where $\mathrm{X}$ is the quercetin equivalent $(\mathrm{QE})$ and $\mathrm{Y}$ is the absorbance (Table 3).

Table 3: Total phenolic and total flavonoid content of Eclipta prostrate (Leaves and seeds)

\begin{tabular}{|c|c|c|c|}
\hline S. No. & Extract & $\begin{array}{c}\text { Total phenol content } \\
\text { (mg/100mg of dried extract) }\end{array}$ & $\begin{array}{c}\text { Total flavonoids content } \\
\text { ( } \mathbf{m g} / \mathbf{1 0 0} \text { mg of dried extract) }\end{array}$ \\
\hline 1. & Leaves & 0.658 & 1.022 \\
\hline 2. & Seeds & 0.457 & 0.633 \\
\hline
\end{tabular}


Table 4 shows the results of antioxidant screening test for hydroalcoholic extract of Eclipta prostrate using DPPH method. The comparative radical scavenging effect of leaves and seeds extracts is shown in table 4. The ascorbic acid and extracts have shown dose dependent scavenging of DPPH radicals. The radical scavenging effect of standard and extracts was in the order ascorbic acid> leaves extract > seeds extract, $\mathrm{IC}_{50}(\mu \mathrm{g} / \mathrm{ml})$ was found to be $17.68,75.28$ and 103.39 respectively.

Table 4: \% Inhibition of ascorbic acid, leaves and seeds hydroalcoholic extract of Eclipta prostrate using DPPH method

\begin{tabular}{|c|c|c|c|c|}
\hline \multirow{2}{*}{ S. No. } & $\begin{array}{c}\text { Concentration } \\
(\mu \mathrm{g} / \mathrm{ml})\end{array}$ & Ascorbic acid & Leaves extract & Seeds extract \\
\cline { 3 - 5 } & 10 & 44.65 & 35.47 & 22.14 \\
\hline 1 & 20 & 48.62 & 38.89 & 29.63 \\
\hline 2 & 40 & 65.34 & 45.26 & 34.96 \\
\hline 3 & 60 & 69.65 & 49.75 & 37.41 \\
\hline 4 & 80 & 77.41 & 51.48 & 41.77 \\
\hline 5 & 100 & 84.13 & 52.36 & 50.20 \\
\hline 6 & $\mathbf{1 7}$ & $\mathbf{1 7 . 6 8}$ & $\mathbf{7 5 . 2 8}$ & $\mathbf{1 0 3 . 3 9}$ \\
\hline
\end{tabular}

$*(n=3$, mean \pm SD $)$

The results of antibacterial activity against $S$. aureus and Klebsiella pneumoniae for leaves and seeds hydroalcoholic extract of Eclipta prostrate. Results indicate that for leaves extract of Eclipta prostrate. Hydroalcoholic extract exhibited the highest antibacterial activity against $S$. aureus and Klebsiella pneumoniae as compare to seeds hydroalcoholic extract of Eclipta prostrate (Table 5).

Table 5: Antimicrobial activity of hydroalcoholic extract of Eclipta prostrate against selected microbes

\begin{tabular}{|c|c|c|c|c|}
\hline \multirow[t]{2}{*}{ S. No. } & \multirow[t]{2}{*}{ Name of microbes } & \multicolumn{3}{|c|}{ Zone of inhibition (Leaves extract) } \\
\hline & & $25 \mathrm{mg} / \mathrm{ml}$ & $50 \mathrm{mg} / \mathrm{ml}$ & $100 \mathrm{mg} / \mathrm{ml}$ \\
\hline 1. & Staphylococcus aureus & $6 \pm 0.57$ & $9 \pm 0.74$ & $10 \pm 0.5$ \\
\hline \multirow[t]{2}{*}{2.} & Klebsiella pneumoniae & $7 \pm 0.5$ & $8 \pm 0.57$ & $9 \pm 0.94$ \\
\hline & & \multicolumn{3}{|c|}{ Zone of inhibition (Seeds extract) } \\
\hline 1. & Staphylococcus aureus & $6 \pm 0$ & $7 \pm 0.94$ & $8 \pm 0.47$ \\
\hline 2. & Klebsiella pneumoniae & $6 \pm 0$ & $6 \pm 0.5$ & $8 \pm 0.94$ \\
\hline
\end{tabular}

Percentage inhibition of $\alpha$-amylase activity by Tinospora crispa leaves extract was estimated with acarbose as the positive control. Tinospora crispa extract show dose dependent activity. $\mathrm{IC}_{50}$ value of acarbose, leaves and seed extract was found to $35.33364 .89 \mu \mathrm{g} / \mathrm{ml}$ and $438.43 \mu \mathrm{g} / \mathrm{ml}$ respectively table 6 .

Table 6: \% Inhibition of acarbose and hydroalcoholic extract of Eclipta prostrate

\begin{tabular}{|c|c|c|c|c|}
\hline S. No. & $\begin{array}{c}\text { Concentration } \\
(\mu \mathrm{g} / \mathbf{m l})\end{array}$ & Ascorbic acid & Leaves extract & Seeds extract \\
\cline { 3 - 5 } & 100 & 51.19 & 25.68 & 26.96 \\
\hline 1 & 200 & 70.10 & 32.43 & 35.85 \\
\hline 2 & 300 & 74.20 & 41.77 & 42.66 \\
\hline 3 & 400 & 85.18 & 55.69 & 47.76 \\
\hline 4 & 500 & 88.75 & 63.24 & 53.25 \\
\hline 5 & $\mathbf{I C}$ & 35.33 & 364.89 & 438.43 \\
\hline
\end{tabular}




\section{CONCLUSION}

In this study, we analyzed the antioxidant, antimicrobial, and antidiabetic activities of Eclipta prostrate. The overall results of this study suggest that the Eclipta prostrate hydroalcoholic leaf extract could be more potent as a source of natural antioxidants compared to seed extract. In addition, the leaf and seeds extract of Eclipta prostrate was shown to possess noteworthy pharmaceutical activities, indicating that Eclipta prostrate should be considered as a useful source for herbal medicine. The difference in medicinal activities between organic extracts suggests that for the isolation and characterization of the active compounds in Eclipta prostrate, a comparative metabolome analysis in leaf extracts would be needed.

\section{REFERENCES}

1. Zhang A, Sun H, Wang X. Recent advances in natural products from plants for treatment of liver diseases. Eur J Med Chem, 2013; 63:570-7.

2. Maiti B, Nagori BP, Singh R, et al. Recent trends in herbal drugs: A review. Int J Drug Res Technol. 2011; 1:17-25.

3. Balasundram N, Sundram K, Samman S. Phenolic compounds in plants and agri-industrial by-products: Antioxidant activity, occurrence, and potential uses. Food Chem. 2006; 99:191-203.

4. Klepacka J, Gujska E, Michalak J. Phenolic compounds as cultivar- and variety-distinguishing factors in some plant products. Plant Foods Hum Nutr. 2011; 66:64-9.
5. Wanger H, Geyer B, Kiso Y, et al. Coumestans as the main active principles of the liver drugs Eclipta alba and Wedelia calendulaceae. Planta Med, 1986; 5:370-74

6. Upadhyay RK, Pandey MB, Jha RN, Pandey VB. Eclalbatin, a triterpene saponin from Eclipta alba. J. Asian Nat.Prod. Res. 2001; 3(3):213-17

7. Jadhav VM, Thorat RM, Kadam VJ, Salaskar KP. Chemical composition, pharmacological activities of Eclipta alba. J. of Pharm. Res.2009; 2(8):1129-1231.

8. Khare CP Encyclopedia of Indian Medicinal Plnats.SpringerVerlag Berlin Heidelberg New York.2004, pp197-198

9. Dalal S, Rana S, Sastry KVS, Kataria S.Wedelolactone as an Antibactrical Agent extracted from Eclipta alba. The Internet J. of Micro. 2009;7:1-11

10. Mukherjee, P. K., (2007). "Quality Control of Herbal Drugs", 2nd Edition, Business Horizons, 2007, 2-14.

11. Khandelwal KR, Practical pharmacognosy technique and experiments. 23 ${ }^{\text {rd }}$ Ed. Nirali Prakashan; 2005.

12. Kokate CK. Practical pharmacognosy. $4^{\text {th }}$ Ed. Vallabh Prakashan; 1994.

13. Olufunmiso 00, Afolayan AJ. phenolic content and antioxidant property of the bark extract of Ziziphus mucronata willd. Subsp. mucronata willd. BMC Complement Altern Med 2011; 11:130.

14. Bauer AW, Kirby WMM, Sherris JC, Turck M. Antibiotic susceptibility testing by a standardized single disk method. American Journal of Clinical Pathology, 1966, 45:493-496. 